\title{
Impact of Gender on Adjustment and Academic Achievement
}

\author{
Dr. Zaki Akhtar ${ }^{1}$, Mahfooz Alam ${ }^{2}$
}

\section{ABSTRACT}

In this era of globalization and demonetization, people of India have become aware of academic excellence and over all development of the students. Education psychologists have brought such issues in the limelight and provided valuable findings contributing to well being of the students. The present paper is an attempt to find out and compare certain areas of adjustment and academic achievement of school students. The sample consisted of 90 students with the age range from 14 to 17 years. Bell Adjustment Inventory developed and standardized by Mohsin and Shamshad (1968) was used to find out adjustment level of students. "t" test was used to analyze the data. Average marks of last three years annual results were considered as academic achievements. The findings showed that boys and girls students differed significantly in overall adjustment process. Although, there were no significant differences among the different level of adjustments i.e. home, health, social and emotional. The results further revealed that high achievement and low achievement students differed significantly in overall adjustment and high academic achievement groups are more adjusted as compare to low academic achievement groups.

Keywords: Adjustment, Academic Achievement, School Students and Gender.

Adjustment and academic achievement are popular expression used by people in day to day life. The concept of adjustment was first used by Darwin, as adaptation to survive in the physical world. Now it is equally popular in the discipline of psychology, sociology and education. The strategy used by the individual to manage this is called adjustment. The process of adjustment starts right from the birth of the child and continues till his death. The problem of adjustment is both internal as well as external. Duncan (1949) defined adjustment as a means of state of harmonious relationship between a person and his environment. It also refers to a continuous process by which a person changes his own behavior or tries to change the environment or brings changes in both to produce satisfactory relationship with his environment. According to Coleman (1969), Adjustment is the outcome of individual's effort to deal with stress and meet his needs.

\footnotetext{
${ }^{1}$ Assistant Professor, Department of Psychology, Karim City College, Jamshedpur, India

${ }^{2}$ Research Scholar, Department of Psychology, Kolhan University, Chaibasa

*Responding Author

(C) 2016 Akhtar Z, Alam M; licensee IJIP. This is an Open Access Research distributed under the terms of the Creative Commons Attribution License (http://creativecommons.org/licenses/by/2.0), which permits unrestricted use, distribution, and reproduction in any Medium, provided the original work is properly cited.
} 
Halonen and Santrock (1997) defined adjustment as the psychological processes used to adapt, cope and manage the problems faced in daily life.

Academic Achievement means knowledge, understanding or skill acquired after instructions and training in courses or subjects of study. It is generally measured by means of total marks of the students obtained by them in a particular class. Academic achievement depends upon different factors which directly or indirectly influence it. Good (1959) defined academic achievement as the knowledge attained or skills developed in the school subjects, usually designated by test scores or marks in the school subjects or by test scores assigned by teacher. Basically it affects cognitive, affective and cognitive aspects of behaviour of the student. Academic achievement refers to the achievement made by the pupils in their subjects of study. It means what pupil has learnt in different subjects. It refers to the pupil's knowledge, attainment and skills developed in the school subjects which are evaluated by the school authorities with the help of achievement test.

Wig and Nagpal (1972) found in their study on mental health and academic achievement -a comparison of successful and failed students and concluded that the failure group had poor adjustment at school and college but not at university. Poor school adjustment leads to low academic achievement, behavioural problems, discordant educational aspirations and even school dropout. Kim (2002) research findings indicate that parental involvement makes a positive contribution to children's educational achievement. In an interesting study, Solomon and Marjorie (2002) found that mothers who were demanding yet responsive, sensitive and having psychologically helping nature had children with overall high adjustment scores. Singh (2006) examined the effects of socio, emotional and socio emotional climate of the school and sex on the adjustment of students along with their interaction effects. Boys were significantly better than girls in their health adjustment at different levels of socio-emotional climate of the school.

Surekha (2008) point out that a significant positive high correlation exists between academic achievement and adjustment. And student of private schools are better adjusted than students of government schools. The students of private schools are better than students of government schools in academic achievement. Mahmondi (2010) found that gender had no differential influence over adjustment scores in home, health, emotional and social area. Lama (2010) reported that there is a great tendency for female students to experience adjustment problems more than males. This finding implies that male students are better adjusted in overall adjustment on the campus as compared to female students. Whereas Roy, Ekka and Ara (2011) observed that female students were better adjusted than male students.

Basu (2012) aimed to investigate the adjustment abilities of secondary school students and found that there exist highly significant differences between the adjustment of secondary school students when compared on the basis of gender, types of family structure and medium of 


\section{Impact of Gender on Adjustment and Academic Achievement}

instruction in school. Yellaiah (2012) found that adjustment and academic achievement cause significant difference between male and female student. Government and private schools students and rural and urban school student do not cause difference between adjustment and academic achievement. It is also found that there is a low positive relationship between adjustment and academic achievement.

Vandana (2013) studied that there is significant difference in adjustment of higher secondary school's students and female students have good adjustment level when compared to the male students. In a study, Makwana and Kaji (2014) found out the Adjustment of Secondary School Students in relation to their gender. The sample consisted of 120 secondary school students. The result shows that there is no significant difference in Home, School and Emotional adjustment of boys and girls. But there is significant difference in Social adjustment of students.

Yengimolki, Kalantarkousheh and Malekitabar (2015) studied to explore the relationship between self-concept and social adjustment with academic achievement of students. The research population was male and female secondary students. The result indicates a significant relationship between self concept and adjustment and academic achievement and social adjustment. The results also indicated that the better adjusted people have the more ability to make progress in their life.

Singh (2016) presented a study to examine the adjustment problems of school student. The findings of the study have shown that adjustment of school students is significantly correlated with their emotional intelligence.

Kaur (2016) find out the Adjustment of Secondary School Students in relation to spiritual intelligence. The results showed that there exists no significant difference between the adjustment of male and female secondary school students. The results also revealed that there exists a positive relationship between the adjustment and spiritual intelligence of secondary school students district.

Sherafat and Murthy (2016) study have attempted to understand whether study habits affect academic achievement among secondary and senior secondary school students. Results indicated that the study habits facilitate higher academic achievement. Further, it was also found that secondary school students are significantly better than senior secondary students on study habits. Thus, study habit is found to be an important correlate of academic achievement.

\section{Objectives}

- The purpose of the present study is to find out academic achievement and adjustment level of school students in relation to home adjustment, health adjustment, social adjustment, emotional adjustment and overall adjustment. 


\section{Hypotheses}

Ho1. Boys and girls school students would not differ significantly on home adjustment.

Ho2. Boys and girls school students would not differ significantly on health adjustment.

Ho3. Boys and girls school students would not differ significantly on social adjustment.

Ho4. Boys and girls school students would not differ significantly on emotional adjustment.

Ho5. Boys and girls school students would not differ significantly on overall adjustment.

Ho6. Boys and girls school students would not differ significantly on academic achievement.

Ho7. High and low academic achievement students would not differ significantly on adjustment level.

\section{METHODOLOGY}

\section{Sample:}

The sample of the present study consists of 90 students studying in class IX to XII from secondary schools of JAC. The participant included 40 boys and 50 girls. Their age ranged from 14 to 17 years.

\section{Measures:}

1. Bell Adjustment Inventory: Mohsin \& Samshad's (1968) Indian adaptation of Bell adjustment inventory was used to assess the adjustment level of sample group. It consists of 134 items. The inventory measures adjustment in four different areas - home, health, social, and emotional. Its reliability ranges from 0.70 to 0.92 and validity is also very high.

2. Average marks of last three years annual results were considered as academic achievement of boys and girls students.

\section{Procedure:}

The respondents were randomly selected from different schools. The academic performance scores of last three years were collected from the school records. Students were administered Bell Adjustment Inventory to check their adjustment level. They were instructed to respond either "Yes" or "No" for each statement. After the completion of questionnaire, they were taken back from the students and were analyzed.

\section{RESULTS AND DISCUSSIONS}

Table-1 Mean, SD and $t$ value of various component of Adjustment among Boys and Girls Students.

\begin{tabular}{|l|l|l|l|l|l|l|l|}
\hline Adjustments & Gender & N & Mean & SD & SED & t value & Level of significance \\
\hline \multirow{2}{*}{ Home Adjustment } & Boys & 40 & 8.05 & 4.46 & 0.95 & 1.63 & $\mathrm{P}>.05$ \\
\cline { 2 - 6 } & Girls & 50 & 9.60 & 4.70 & & & \\
\hline $\begin{array}{l}\text { Health } \\
\text { Adjustment }\end{array}$ & Boys & 40 & 7.42 & 3.76 & 1.72 & 1.38 & $\mathrm{P}>.05$ \\
\cline { 2 - 7 } $\begin{array}{l}\text { Social } \\
\text { Adjustment }\end{array}$ & Girls & 50 & 9.80 & 4.10 & & & \\
\cline { 2 - 8 } & Boys & 40 & 15.62 & 4.59 & 0.93 & 0.68 & $\mathrm{P}>.05$ \\
\hline
\end{tabular}


Impact of Gender on Adjustment and Academic Achievement

\begin{tabular}{|l|l|l|l|l|l|l|l|}
\hline Adjustments & Gender & $\mathbf{N}$ & Mean & SD & SED & t value & Level of significance \\
\hline $\begin{array}{l}\text { Emotional } \\
\text { Adjustment }\end{array}$ & Boys & 40 & 69.33 & 8.28 & 2.43 & 0.67 & $\mathrm{P}>.05$ \\
\cline { 2 - 7 } $\begin{array}{l}\text { Overall } \\
\text { Adjustments }\end{array}$ & Girls & 50 & 68.00 & 10.48 & & & \\
\cline { 2 - 8 } & Goys & 40 & 10.69 & 5.44 & 0.59 & 4.06 & $\mathrm{P}<.01$ \\
\hline
\end{tabular}

Table-2 Mean, SD and t value of Academic Achievement of Boys and Girls Students

\begin{tabular}{|l|l|l|l|l|l|l|l|}
\hline Variable & Gender & $\mathbf{N}$ & Mean & SD & SED & t value & Level of significance \\
\hline $\begin{array}{l}\text { Academic } \\
\text { Achievement }\end{array}$ & Boys & 40 & 206.9 & 30.2 & 9.45 & 5.48 & $\mathrm{P}<.01$ \\
\cline { 2 - 5 } & Girls & 50 & 258.7 & 57.7 & & & \\
\hline
\end{tabular}

Table-3 Mean, SD and $t$ value of Adjustment among High and Low Academic Achievement Students.

\begin{tabular}{|l|l|l|l|l|l|l|}
\hline Groups & N & Mean & SD & SED & t value & Level of significance \\
\hline $\begin{array}{l}\text { High Academic } \\
\text { Achievement }\end{array}$ & 35 & 30.15 & 12.37 & 1.48 & 2.81 & $\mathrm{P}<.01$ \\
\cline { 1 - 4 } Low Academic Achievement & 55 & 36.41 & 11.44 & & & \\
\hline
\end{tabular}

Table no. 1 shows the t-value of home adjustment dimensions of boys and girls students. Since the calculated t-value 1.38 is less than table value of 1.98 at 0.05 levels of significance. Thus the hypothesis 1 stating "Boys and girls school students would not differ significantly on home adjustment" is accepted in the area of a home adjustment. Ganai and Ashraf (2013) got the similar findings that there is no significant difference between male and female college students in terms of home adjustment. In this regard Vishal (2014) obtained the result that boys and girls school students differ significantly in relation to home adjustment. The home adjustments of boys were higher than the girls.

Health adjustment dimensions of boys and girls students calculated t-value 1.38 is less than the table value of 1.98 at 0.05 level of significance. Thus the hypothesis 2 stating "Boys and girls school students would not differ significantly on health adjustment" is accepted in the area of health adjustment. Roy and Ghosh (2012) also confirmed in their study that early and late adolescent boys and girls were not significantly differed in health adjustment, whereas study of Dutta, Baratha \& Goswami (1997) demonstrate significant differences between health adjustment of girls and boys students.

Social adjustment dimension of boys and girls calculated t-value 0.68 is less than table value of 1.98 at 0.05 levels of significance. Thus, the hypothesis 3 stating "Boys and girls school students would not differ significantly on social adjustment” is accepted in the area of social adjustment. Muni \& Pavigrahi (1997) found that girls are better adjusted in social adjustment as compared to 
boys. Another study by Gupta and Gupta (2011) revealed female children were better in social adjustment while in educational adjustment boys and girls have same order of adjustment.

Emotional adjustment dimensions of boys and girls student calculated t-value 0.67 is less than the table value of 1.98 at 0.05 levels of significance. Thus the hypothesis 4 stating "Boys and girls school students would not differ significantly on emotional adjustment". is accepted in the area of emotional adjustment. Some studies conducted on this dimensions which contradict this finding. Muni \& Pavigrahi (1997) concluded that girls were better adjusted than the boys in emotional adjustment area. In a study Rahamtullah (2007) stated that boys are significantly better adjusted than girls on the emotional adjustment area.

Overall adjustment dimensions of boys and girls students calculated t-value 4.06 is more than the table value of 2.63 at 0.01 levels of significance. Thus the hypothesis 5 stating "Boys and girls school students would not differ significantly on overall adjustment "is rejected in the area of overall adjustment. Some studies conducted on this dimensions which contradict this finding. Manju (2011) studies the adjustment among high school students with respect to their gender and found no significant differences in the emotional, social, educational and the total adjustment of students with respect to their gender. Gupta (2013) study was design to compare different adjustment problem faced by boys and girls of senior secondary school. The sample consisted of 50 boys and 50 girls from 5 government and private senior secondary schools. Results confirmed all the hypothesis of significant difference between the problems of adjustment among senior secondary school students. Thakar and Modi (2014) also confirmed this finding with reference to overall adjustment.

Table no. 2 academic achievement of boys and girls students calculated t-value 5.48 is more than the table value of 2.63 at 0.01 levels of significance. It means boys differ significantly as compared to their counterparts. It can be seen in mean score also. Thus the hypothesis 6 stating "Boys and girls school students would not differ significantly on academic achievement" is rejected in the area of academic achievement. Maureen, John and Ayere (2011) made a study on school adjustment in relation to academic achievement and gender which revealed that there were no significant differences between girls and boys in school adjustment. Whereas Vijayalaxmi and Natesan (1992) studied factors influencing academic achievement and their findings showed that girls had a higher mean academic achievement compared to boys.

Table no. 3 indicates mean score on adjustment of school students having high academic achievement is 30.15 and low academic achievement is 36.41 . The $t$ value 2.81 is more than the table value of 2.63 at 0.01 levels of significance. The result indicates that the two groups are significantly different. So, it can be concluded that school students having high academic achievement and low academic achievement are significantly different on adjustment. Thus the 
hypothesis 7 stating "High and low academic achievement students would not differ significantly on adjustment level" is rejected in the area of academic achievement.

Agarwal (2003) conducted a comparative study of adolescent's level of adjustment in relation to the academic success and failure. It was found that successful adolescents were significantly superior in their social emotions and educational adjustment in comparison to unsuccessful adolescents. Adhiambo, Odwar and Mildred (2011) investigated the levels of school adjustment and its relationship with academic achievement. The results showed no significant differences between girls and boys in school adjustment and significant differences between high achievers and low achievers in dedication, absorption, engagement and school adjustment.

\section{CONCLUSIONS}

There were no significant differences found among boys and girls students with regard to various component of adjustment. The two genders also not differ in terms of scores obtained separately on any dimension of the adjustment. Furthermore, result revealed significant difference in terms of their overall adjustment and academic achievement.

\section{Acknowledgments}

The author appreciates all those who participated in the study and helped to facilitate the research process.

\section{Conflict of Interests}

The author declared no conflict of interests.

\section{REFERENCES}

Adhiambo W. M., Odwar, A. J. \& Mildred, A. A. (2011). The relationship among school adjustment, gender and academic achievement amongst secondary school students in Kisumu district Kenya. Journal of Emerging Trends in Educational Research and Policy Studies, 26, 493-497.

Agarwal, K. (2003). A comparative study of adolescent's level of adjustment in relation to the academic success and failure. Indian Journal of Psychometric and Education, 134 (2), 172- 176.

Basu, S. (2012). Adjustment of secondary school students. Scholarly Research Journal for Interdisciplinary Studies, 1(3), 430-438.

Coleman, J. C. (1969). Abnormal psychology and modern life, 3rd Ed. Born bay, Taraporevala and Co. (p) Ltd.

Duncan, M. H. (1949). Home adjustment of stutterers and non-stutterers. Journal of Speech and Hearing Disorders, 14,225-259.

Dutta, M., Baratha, G. \& Goswami, U. (1997). Health adjustment of adolescents. Indian Psychological Review, 48(3), 84-86. 
Ganai, M. Y. \& Ashraf, M. M. (2013). A comparative studies of adjustment and academic achievement of students. Journal of Educational Research and Essays, 1(1), 5- 8.

Good, C. V. (1959). Director of education, New York: Mc Graw Hill.

Gupta, M. \& Gupta, R. (2011). Adjustment and scholastic achievement of boys and girls. VSRD International Journal of Business and Management Research,1, 20-26.

Gupta, N. (2013). A study of problems of Adjustment of Senior Secondary School Students. Conflux Journal of Education. 1(2), 93-94.

Halonen, J. S. \& Santrock, J. W. (1997). Human Adjustment. New York: McGraw Hill.

Kaur, P. (2016). A study of adjustment among secondary school Students in relation spiritual intelligence. International Educational E-Journal, V(I), 103-108.

Kim, E. (2002). The relationship between parental involvement and children's educational achievement in the Korean immigrant family. Journal of Comparative Family Studies, 33 (4), 529-543.

Lama, M. (2010). Adjustment of college Freshman: The importance of gender and place of residence. International Journal of Psychological Studies, 2(1), 142-150.

Mahmondi, A. (2010). Influence gender on adjustment among adolescent. Journal of Social Science Research, 2, 53 - 64.

Makwana, M. D. \& Kaji, S. M. (2014). Adjustment of Secondary School Students in Relation to their Gender. The International Journal of Indian Psychology,2(1),5-12.

Manju, G. (2011). A study of adjustment among high school students in relation to their gender. International Referred Research Journal, 3(33), 14-15.

Maureen, W., John, A. \& Ayere, A. M. (2011). The relationship among school adjustment, gender and academic achievement amongst secondary school students in Kisumu district Kenya. Journal of Emerging Trends in Educational Research and Policy Studies, 2(6), 493-497.

Mohsin, S. (1968). Manual for Mohsin-Samshad hindi adaptation of Bell Adjustment Inventory.

Muni, A. K. \& Pavigrahi, B. (1997). Effect of maternal employment on school going children's adjustment problems. Journal of Common Guidance and Research, 4(3), 209-216.

Rahamtullah, K. (2007). Adjustment problems among school children. Journal of the Indian Academy of Applied Psychology, 33 (1), 73-79.

Roy, B., Ekka, A. \& Ara, A. (2010). Adjustment among university students. Journal for Social Development, 2 (2), ISDR. Ranchi.

Roy, B. \& Ghosh, S. M. (2012). Pattern of adjustment among early and late adolescent school students. International Indexed \& Referred Research Journal, 4(42), 20-21.

Sherafat, R. \& Murthy, C. G. V. (2016). A Study of Study Habits and Academic Achievement among Secondary and Senior Secondary School Students of Mysore City. The International Journal of Indian Psychology, 3(2), 161-170.

Singh, H. (2006). Effect of socio- emotional climate of the school on the adjustment of students. Psycho lingua, 36 (2), 133-143. 
Singh, R. (2016). A study of secondary school students adjustment in relation to their emotional intelligence. EPRA International Journal of Economic and Business Review, 4(5), 86-89.

Solomon \& Marijorie (2002). The fruits of their labors: A longitudinal exploration of parent personality and adjustment in their adult children. Journal of Personality, 68 (2), 281-308.

Surekha (2008). Relationship between students' adjustment and academic achievement. Edu. Track, 7(7), 26-31.

Thakar, K. R., \& Modi, N.K. (2014). A study of adjustment on academic achievement of high school students. International Journal of Research in all Subjects in Multi Languages, 2(7), 18-21.

Vandana, C. (2013). A study on adjustment of higher secondary school students of Durg district. OSR Journal of Research \& Method in Education, 1 (1), 50-52.

Vijayalaxmi, N., \& Natesan, H. (1992). Factors influencing academic achievement. Research Highlights, 2, 62-68.

Vishal, P. \& Kaji, S. M. (2014). Adjustment of boys and girls school level students in Ahmedabad . International Journal of Indian Psychology, 2(1), 48-53.

Wig, N. N. \& Nagpal, R. N. (1972). Mental health and academic achievement-A comparison of successful and failed students. Education and Psychology Review, 12, 31-39.

Yellaiah (2012). A study of adjustment on academic achievement of high school student. International Journal of Social Science and Interdisciplinary Research, (1)5, 22-30.

Yengimolki, S., Kalantarkousheh, S. M. \& Malekitabar, A. (2015). Self-Concept, Social Adjustment and Academic Achievement of Persian Students. International Review of Social Sciences and Humanities, 8(2), 50-60.

How to cite this article: Akhtar Z, Alam M (2016), Impact of Gender on Adjustment and Academic Achievement, International Journal of Indian Psychology, Volume 4, Issue 1, No. 80, ISSN:2348-5396 (e), ISSN:2349-3429 (p), DIP:18.01.105/20160401, ISBN:978-1-365-57867-0 